\title{
Genetic Variability, Heritability and Genetic Advances in Wheat (Triticum aestivum L.) under Cold Arid Conditions of Kargil
}

\author{
Mushtaq Ahmad ${ }^{*}$, Faizan Ahmad ${ }^{1}$, Eajaz Ahmad Dar', Tahmina Mushtaq ${ }^{1}$, \\ Shahida Iqbal ${ }^{1}$, Fozia Shah ${ }^{1}$ and Rizwan Rashid ${ }^{3}$ \\ ${ }^{1}$ Mountain Agriculture Research and Extension Station, Kargil-194103, India \\ ${ }^{2}$ Krishi Vigyan Kendra Kargil-194103, India \\ ${ }^{3}$ Krishi Vigyan Kendra Zanskar-194103, India \\ ${ }^{4}$ Sher-e-Kashmir University of Agricultural Sciences \& Technology of Kashmir, Jammu \& \\ Kashmir, Srinagar-190025, India \\ *Corresponding author
}

\section{A B S T R A C T}

A study was undertaken to estimate the heritability, genetic advance and coefficient of variation of yield and yield contributing traits in thirteen genotypes of wheat. The study was conducted in randomized block design (RBD) with three replications at Mountain

Keywords

Wheat, Genotypic

coefficient of variation,

Phenotypic coefficient of

variation, Heritability,

Genetic advances

Article Info

Accepted:

12 October 2018

Available Online:

10 November 2018
Agriculture Research and Extension Station, Kargil (SKUAST-Kashmir) during kharif season of 2018. Significant genetic differences were observed for all the quantitative characters except flag leaf width, indicating considerable amount of variation among genotypes. The higher magnitude of phenotypic coefficient of variation (PCV) was recorded for harvest index. The high heritability was estimated for the characters like harvest index, days to $50 \%$ flowering, plant height, flag leaf length, spike length and number of grains per spike. High heritability coupled with high genetic advance as percent of means was recorded for harvest index, plant height, spike length and grains per spike that indicated predominance of additive gene action in the inheritance of these traits. However in most of the cases, high genetic advanced was not accompanied with high heritability. High estimate of heritability $(\mathrm{H} 2)$ was seen for most of the traits and moderate genetic advance was observed for number of tillers per plant and number of grains per spike. Exercising of selection pressure on these characters will be fruitful in improvement of the crop for yield.

\section{Introduction}

Wheat $(2 n=6 x=42)$ belongs to family Poaceae and Triticum genera. Spring wheat or bread wheat (Triticum aestivum L. em Thell), which comes under aestivum species, is the most common and widely grown wheat at global level as well as in India. Other types of wheat like Triticum durum, Triticum dicoccum are also grown on a limited area for their special significance in developing products for human consumption Saleem et al., (2015a). Wheat flour is the main product of wheat produce, from which various kinds of human foods are being developed. Wheat is the main cereal crop of Ladakh region with highest acreage 
among all cereal crops being cultivated in Ladakh, but its yield is low due to lack of high yielding varieties, limited water availability, poor soil fertility and low organic matter content. Hence different strategies are required to increase the productivity of wheat.

Historically, subsistence agriculture has formed the organising structure of both society and the economy (LAHDC-Leh 2011). With scarce water availability (almost no rainfall, and reliance on glacial meltwater channels and springs), the villages are scattered between small areas of land in the river valleys of the Indus, and its tributaries Shayok and Zanaskar. Pastoral herding of yak, sheep and goats suits both nomadic and settled communities, while the latter also cultivate barley, wheat and peas, and horticultural crops like apricot and apple. Seasonal patterns of agricultural production drive village activity. The arable agricultural schedule is tightly constrained: the growing season is extremely short (between May and September). Sowing occurs between $20^{\text {th }}$ March-25th May, and harvesting between $15^{\text {th }}$ August and $15^{\text {th }}$ September. As a result, farmers in Ladakh are extremely risk-averse in adopting untested technology.

Jammu and Kashmir has diverse agro-climatic conditions ranging from sub-tropical to temperate cold desert and wheat is gown in all these regions. Wheat is grown in an area of about 266 thousand hectare with annual production of 4983 thousand quintals with an average productivity of $19.0 \mathrm{q} / \mathrm{ha}$ in the state (Anonymous, 2006-07). Kargil district is located between 320-360 N latitude and 760$790 \mathrm{E}$ longitude at an altitude ranging between $2,700 \mathrm{~m}$ to about $4,200 \mathrm{~m}$ above mean sea level with a total geographical area of 14,036 square kilometres. In Kargil district wheat is grown as a kharif/summer crop unlike in other parts of the country where it is grown as a winter crop and is second most important crop of the region. Due to severity of winter, wheat fits only in the mono-cropping situation covering an area of 2.50 thousand hectare with annual production of 40 thousand quintals and average productivity of $16 \mathrm{q} \mathrm{ha}^{-1}$. Though, the agro-climatic conditions are best suited for higher productivity of wheat but due to its long duration, farmer's preference is for short duration barley which after harvest can be easily followed by 45-50 days fodder crop cultivation. In the region people are generally worried about fodder as they have to stall feed their cattle for about 7-8 months due to harsh winter. Fodder is a scarce commodity and sometimes fetches higher price than the grain in the region.

The wheat breeders are concentrating to improve the yield potential of wheat by developing new varieties. Wheat is a selfpollinated crop and can be grown successfully in both tropical and subtropical areas. Wheat attains unique prominent position in agriculture and economic perspective of our country because of being second most important food crop after rice. In past three and half decades, India has achieved tremendous increase in production, area and productivity of wheat.

The most important factor responsible for unfurling such pleasant scenario in wheat production has been the release of dwarf and semi-dwarf, fertilizer responsive, lodging resistant, day length insensitive and widely adopted high yielding varieties of wheat (Saleem et al., 2015b). It is widely known thatgenetic variability provides a broad scope for selection. Hence in the present investigation, an attempt was made to assess the variability of important grain and biological yield contributing traits along with the indication of their variability viz., genotypic coefficient variation (GCA), phenotypic coefficient of variation (PCV), heritability in broad sense (h2bs) and genetic advance (GA) percent of mean. 


\section{Materials and Methods}

Thirteen (13) genotypes of wheat (Triticum aestivum L.) were obtained from the National Bureau of plant genetic resources, New Delhi and evaluated at Mountain Agriculture Research and Extension Station, Kargil (SKUAST-Kashmir) during kharif season of 2018. The experiment was laid out in randomized block design with three replications. The experimental materials consist of thirteen genotype of wheat viz., SAPTDNARA, HPW42, HSC75, HPW155, HS507, VL616, VL829, VL832, HS207, VL616, VL829, VL832, HS207, HPW251, MANSAROVAR, SKW196 and KAILASHM. All the genotypes were evaluated and characterized for various traits i.e. day of $50 \%$ flowering, days to maturity, grain filling period (days), plant height $(\mathrm{cm})$, flag leaf length $(\mathrm{cm})$, flag leaf breadth $(\mathrm{cm})$, number of tillers per/plant, spike length $(\mathrm{cm})$, number of grain per spike, grain weight per main spike $(\mathrm{g}), 1000$ grain weight $(\mathrm{g})$, grain yield per plant $(\mathrm{g})$, biological yield per plant (g) and harvest index (HI, \%). The data was subjected to analysis of variance to test the level of significance among the genotypes for different characters according to Steel \& Torrie (1981). The GCV and PCV were estimated as per Burton (1953) and Johnson et al., (1955), respectively.

Genotypic coefficient of variation $(\mathrm{GCV} \%)=$ $(\sigma 2 \mathrm{~g} / \mathrm{x}) \times 100$

Phenotypic coefficient of variation $(\mathrm{PCV} \%)=$ $[(\sigma 2 \mathrm{~g}+\sigma 2 \mathrm{gy}+\sigma 2 \mathrm{e}) / \mathrm{x}] \times 100$

Heritability and Genetic advances were calculated as per Allard (1960).

\section{Results and Discussion}

Analysis of variance for the experiment with thirteen treatments for fourteen characters viz., days to $50 \%$ flowering, days to maturity plant height, grain filling period (days), number of tillers per plant, spike length, number of grains per spike, flag leaf length, flag leaf width, 1000 grains weight, grain weight per main spike (g) biological yield per plant $(\mathrm{g})$ harvest index (HI) (\%) and grain yield per plant was carried out for testing the significance of variance among the treatments for each character through ' $F$ ' test (Table 1). The ' $F$ ' test indicated that variance due to treatments were highly significant for all the characters except flag leaf width under study. The variance due to known and unknown causes was worked out using the method suggested by Lush (1949) (Table 1).

\section{Descriptive statistics}

The mean and range was calculated for all the studied characters (Table 2). The mean days taken to 50\% flowering and maturity were 65 and 100 with a range varying from 59-72 and $95-105$, respectively. The variation in phenological parameters may be due to genetic characteristic of the genotypes. The range was wider for grain filling period, number of grains per spike and yield while as the range was narrow for plant height and 1000 grain weight. The mean grain yield and biological yield was 8.7 and $31.3 \mathrm{~g} / \mathrm{plant}$, respectively. The variation in genotype characters may be harnessed for selection of improved genotype.

\section{Coefficient of variation}

Phenotypic and genotypic coefficient of variation, heritability estimates and predicted genetic advance as per cent of mean for characters are presented in Table 2. The estimates of coefficient of variation, i.e. genotypic coefficient of variation (GCV) and phenotypic coefficient of variation (PCV) along with general mean and range for all the traits are presented in Table 2 . 
Table.1 Analysis of variance for yield and yield components in wheat

\begin{tabular}{|c|c|c|c|c|c|c|c|c|c|c|c|c|c|c|c|}
\hline $\begin{array}{l}\text { Source of } \\
\text { variation }\end{array}$ & df & $\begin{array}{l}\text { Day of } \\
\mathbf{5 0 \%} \\
\text { flowering } \\
\text { (Days) }\end{array}$ & $\begin{array}{l}\text { Days to } \\
\text { maturity } \\
\text { (Days) }\end{array}$ & $\begin{array}{l}\text { Grain } \\
\text { filling } \\
\text { period } \\
\text { (Days) }\end{array}$ & $\begin{array}{l}\text { Plant } \\
\text { height(cm) }\end{array}$ & $\begin{array}{l}\text { Flag leaf } \\
\text { length } \\
(\mathrm{cm})\end{array}$ & $\begin{array}{l}\text { Flag leaf } \\
\text { width } \\
\text { (cm) }\end{array}$ & $\begin{array}{l}\text { Tillers/ } \\
\text { plant }\end{array}$ & $\begin{array}{l}\text { Spike } \\
\text { length } \\
(\mathrm{cm})\end{array}$ & $\begin{array}{l}\text { Grains/ } \\
\text { spike }\end{array}$ & $\begin{array}{l}\text { Grain } \\
\text { weight } \\
\text { per main } \\
\text { spike (g) }\end{array}$ & $\begin{array}{l}\text { Grain } \\
\text { yield } \\
\text { (g/plant) }\end{array}$ & $\begin{array}{l}1000 \\
\text { grain } \\
\text { weight } \\
\text { (g) }\end{array}$ & $\begin{array}{l}\text { Biological } \\
\text { yield } \\
\text { (g/plant) }\end{array}$ & $\begin{array}{l}\text { Harvest } \\
\text { index }(\%)\end{array}$ \\
\hline Replication & 2 & 0.324 & 1.013 & 0.786 & 1.098 & 0.412 & 0.003 & 1.654 & 0.721 & 2.098 & 1.003 & 1.098 & $0 . .615$ & 2.012 & 1.088 \\
\hline Treatments & 12 & $44.345^{* * *}$ & $562.056 * *$ & $674.097 * *$ & $277.271 * *$ & $14.025 * *$ & 0.039 & $5.749 * *$ & $8.102 * *$ & $156.109 * *$ & $132.009 * *$ & $21.786 * *$ & $45.262 * *$ & $49.099 * *$ & 243.099** \\
\hline Error & 24 & 1.816 & 1.089 & 1.342 & 1.046 & 1.228 & 0.018 & 1.374 & 0.416 & 1.331 & 1.089 & 20.165 & 17.177 & 12.087 & 2.090 \\
\hline
\end{tabular}

Table.2 Mean, range, GCV, PCV, Heritability and genetic advance in wheat

\begin{tabular}{|c|c|c|c|c|c|c|c|}
\hline Character & Mean & Range & GCV & PCV & Heritability & $\begin{array}{l}\text { Genetic } \\
\text { Advance }\end{array}$ & $\begin{array}{c}\text { Genetic Advancement as per } \\
\text { mean }\end{array}$ \\
\hline Day of $50 \%$ flowering (Days) & 65.4 & $59.3-71.5$ & 10.3 & 12.2 & 85.2 & 13.4 & 20.6 \\
\hline Days to maturity (Days) & 100.1 & $95.4-104.7$ & 4.7 & 6.2 & 81.5 & 11.2 & 11.2 \\
\hline Grain filling period (Days) & 41.6 & $32.6-50.6$ & 13.3 & 15.2 & 84.9 & 12.2 & 29.4 \\
\hline Plant height $(\mathrm{cm})$ & 65.8 & $60.2-71.4$ & 8.3 & 9.2 & 87.5 & 13.3 & 20.3 \\
\hline Flag leaf length (cm) & 13.3 & $11.2-15.3$ & 6.3 & 7.4 & 66.3 & 3.9 & 29.3 \\
\hline Flag leaf breadth (cm) & 1.7 & $1.4-2.0$ & 5.8 & 9.9 & 34.1 & 0.1 & 6.9 \\
\hline Number of tiller per/plant & 8.8 & $6.0-12.3$ & 13.8 & 19.2 & 51.5 & 1.8 & 20.4 \\
\hline Spike length (cm) & 10.4 & $7.1-13.6$ & 15.4 & 16.6 & 86.0 & 3.1 & 29.5 \\
\hline $\begin{array}{l}\text { Number of grain per Spike } \\
\text { (No.) }\end{array}$ & 42.7 & $35.2-50.2$ & 11.5 & 14.5 & 59.4 & 4.6 & 10.7 \\
\hline $\begin{array}{l}\text { Grain weight per main spike } \\
\text { (g) }\end{array}$ & 2.3 & 1.9 to 2.8 & 22.2 & 25.1 & 80.2 & 1.5 & 62.4 \\
\hline 1000 grain weight $(\mathrm{g})$ & 37.2 & $35.2-39.2$ & 7.2 & 10.1 & 35.1 & 5.2 & 14.0 \\
\hline Grain yield per plant (g) & 8.7 & $7.5-10.0$ & 10.0 & 16.3 & 15.3 & 1.0 & 11.5 \\
\hline Biological yield per plant (g) & 31.3 & $18.3-44.2$ & 26.4 & 27.0 & 88.3 & 17.2 & 55.1 \\
\hline Harvest index (\%) & 33.9 & $22.2-45.5$ & 28,44 & 29.2 & 91.4 & 22.7 & 67.0 \\
\hline
\end{tabular}


High genotypic coefficient of variation (>25\%) was observed for biological yield and harvest Index. Moderate genotypic coefficient of variation (10-25\%) was observed for number of tillers per plant, spike length and number of grains per spike. Days to maturity, plant height flag leaf length, flag leaf width,1000 grain weight and grain yield per plant showed low $(<10 \%)$ genotypic coefficient of variation (Table 2).

High percentage of phenotypic coefficient of variation (more than 25\%) was observed for grain weight per spike, biological yield and harvest index. Moderate phenotypic coefficient of variation (10-25\%) was observed for days of $50 \%$ flowering, number of tiller per/plant, spike length $(\mathrm{cm})$, number of grain per Spike and 1000 grain weight $(\mathrm{g})$. Days to maturity, plant height $(\mathrm{cm})$ flag leaf length and flag leaf width showed low $(<10 \%)$ phenotypic coefficient of variation (Table 2). These results are in agreement with the findings of Bhushan et al., 2103 and Rathwa et al., 2018.

\section{Heritability}

High heritability ( $>60 \%)$ was observed for the characters viz.,days to $50 \%$ flowering, days to maturity, grain filling period, plant height, flag leaf length, spike length, grain weight per spike, biological yield and harvest Index. Moderate (30-60\%) heritability was recorded for flag leaf breadth, number of tillers per/plant and number of grain per spike. Low heritability (below 30\%) was recorded only for grain yield per plant (Table 2). These findings are in agreement with the results of Gupta et al., (2011).

\section{Expected genetic advance as percentage of mean}

Expected genetic advance expressed as percentage of mean was observed high (>
$20 \%$ ) for day of $50 \%$ flowering, grain filling period, plant height, flag leaf length, number of tillers per plant, spike length, grain weight per spike, biological yield per plant and harvest index. Moderate genetic advance as percent of mean (10-20\%) was recorded for days to maturity, flag leaf breadth, number of grain per spike and grain yield per plant (Table 2). These findings are in agreement with Ratwa et al., (2018).

High heritability was revealed for most yield contributing traits like grain yield per plant, number of spikelets per spike, plant height and grain weight per ear. The high heritability indicates that the characters are less influenced by environment. Similar results were also found by Liu and Ma (1994), Deswal et al., (1996), Yadav et al., (2003) and Ansari et al., (2004). Moderate GCV, $\mathrm{PCV}$, heritability and genetic advance was observed for number of tiller per plant and harvest index. It is indicated that these parameters are governed by additive gene action and could be equally improved through selection.

\section{References}

Allard, R.W. (1960). Principles of plant breeding. John Willey and Sons. Inc., New York

Anonymous (2006-07). Digest of Statistics. Directorate of Economics and Statistics. Govt. of J\&K. pp 94, 101.

Anonymous. (2009). Department of Agriculture, Kargil Government of Jammu and Kashmir.

Ansari, KA, Ansari, BA, Amanullah, K (2004) Extent of heterosis and heritability in some quantitative character of bread wheat. Ind Genet 4: 226-236.

Bharat B, Gaurav, S, Ravindra, K, Rishi, P, Manoj, P, Anant, K, Sonu, B, Nagar, SS, Rahul, VP (2013). Genetic 
Variability, Heritability and Genetic Advance in Bread Wheat (Triticum aestivum L.). Environment \& Ecology 31 (2): 405-407

Burton, G. M. and DeVane, E. M. 1953. Estimating heritability in tall Fescue from replication clonal material. Agron. J., 45: 478-481.

Deswal, RK, Grakh, SS, Berwal KK (1996) Genetic variability and characters association between gr-ain yield and its components in wheat. Ann Boil, Ludhiana 12: 221-224.

Gupta, AK, Mittal, RK, Ziauddin, A, Prasad, RN, Ahmad, Z (2011) Genetic divergence analysis in spring wheat (Triticum aestivum L.). Ind J Genet 56: $556-562$.

Johnson, H. W., Robinson, H. F. and Comstock, R. E. 1955.Genotypic and phenotypic correlations in soybeans and their implications in selection. Agron. J., 47: 477-483.

LAHDC-Leh (Ladakh Autonomous Hill Development Council - Leh) 2011. District Profile. Online, available at http://leh.gov.in/pages/leh.pdf

Liu, CF, Ma, SM (1994) Study of heritability, genetic advance and correlation of the main agronomic characters in spring wheat. Ningxia J Agric Forest Sci Tech 32: 20.

Lush JL (1949). Heritability of quantitative characters in farm animals. Herbicides 35: 356-357.

Mughal, AH, Rai, HK., Sharma, VK, Singhal, SK, and Manoj, P. (2011). Realising Production Potential Wheat in Cold
Arid. Indian Res. J. Ext. Edu. 11 (3) 4551

Pelliciardi V. (2010). Sustainability Perspectives of Development in Leh District (Ladakh, Indian TransHimalaya): an Assessment. CIRPS, University of Rome Sapienza: PhD Thesis.

Rathwa, HK, Pansuriya, AG, Patel, JB, and Jalu, RK (2018). Genetic Variability, Heritability and Genetic Advance in Durum Wheat (Triticum durum Desf.) International Journal of Current Microbiology and Applied Sciences., 7(1): 233-239

Saleem, N., Ahmad, M., Wani, S.A., Vashnavi, R., Dar, Z.A. (2015b). Genotype-environment interaction and stability analysis in Wheat (Triticum aestivum L.) for protein and gluten contents. Scientific Research and essays., 10(7): 260-265.

Saleem, N., Ahmad, M., Vashnavi, R., Bukhari, A., Dar, Z.A. (2015a). Stability analysis in Wheat: An application of additive main effects and multiplicative interaction. African $J$. Agric. Res., 10(4): 295-300.

Steel, R.G.D. and J.H. Torrie. (1981). Principles and Procedures of Statistics. 2nd Edition, McGraw-Hill Book Co., Inc., New York, USA, 633p.

Yadav, RK, Khan, P, Singh, P (2003) Heritability and genetic advance in common wheat (Triticum aestivum L.). Farm Sci., 12: 163-164.

\section{How to cite this article:}

Mushtaq Ahmad, Faizan Ahmad, Eajaz Ahmad Dar, Tahmina Mushtaq, Shahida Iqbal, Fozia Shah and Rizwan Rashid. 2018. Genetic Variability, Heritability and Genetic Advances in Wheat (Triticum aestivum L.) under Cold Arid Conditions of Kargil. Int.J.Curr.Microbiol.App.Sci. 7(11): 1456-1461. doi: https://doi.org/10.20546/ijcmas.2018.711.168 